\title{
COMPOSITION, STRUCTURE AND ORGANIZATION OF MIXED-SPECIES BIRD FLOCKS IN WALAUWATTA-WATURANA SWAMP FOREST, KALUTARA DISTRICT, WESTERN PROVINCE OF SRI LANKA.
}

\author{
P G D Ratnayake', M S J Perera² and U K G K Padmalal \\ 1Open University of Sri Lanka \\ 2IUCN- The World Conservation Union, Sri Lanka
}

\begin{abstract}
Mixed- species foraging bird flocks in Walauwatta-Waturan Swamp Forest (WWSF) were studied for a period of six months from February to July in 2001. Field data was collected from 07:00 to 18:00 hrs and flocks were followed as long as possible to record their composition. Scan sampling method (Altman, 1975) was used to record their behavioural activity, height of feeding, feeding site and the role of each individual within the flock. Two minute scan samples were done with five minute intervals and almost all the birds participating in the flock were scanned within the two minutes time period.
\end{abstract}

The flocking tendency of birds in WWSF was $28.7 \%$ and 27 flocks were studied. A total of 31 bird species were recorded to participate in mixed-species flocks in WWSF. These include 28 resident and 3 migrate species. Five species were endemic to Sri Lanka. The flock composition varied from 3 to 15 species $(5.89 \pm 2.61)$ and 4 to 31 individuals $(12.96 \pm 7.41)$. There was a positive correlation between the number of species and flock size $(I=0.796)$.

Crested Drongo (77.78\%) and Black-naped Monarch (70.37\%) were the most frequent birds found in flocks while Sri Lanka Orange-billed Babbler was the most abundant $(8.78 \pm 3.67$ individuals per flock). Territorial species such as Purple-rumped Sunbird joined the flock when it was passing through their territory. Birds in mixed-species flocks in WWSF were classified as nuclear species, lead species, regular species, and occasional species. 2 major nuclear species (Crested Drongo \& Sri Lanka Orange-billed Babbler), 4 lead species (Above two with Malabar Trogon and Asian Paradise Flycatcher), 12 regular species, and 15 occasional species were identified. Associations of bird species participating in mixed species flocks in WWSF were studied using cluster analysis. Two main clusters could be identified, one of which could be again divided into two subassociations. The first cluster comprised of Crested Drongo and Black-naped Monarch who showed the highes: level of association. Black Bulbul and Sri Lanka Orange-billec' Babbler could not be pooled into any clusters.

Different species in mixed species flocks had different optimum height levels of movement through the forest and appeared to have characteristic feeding sites. The vertical distribution of the regular species in flocks was consistent. Sri Lanka Orange-billed Babbler was found at a wide range of foraging heights. But, Scarlet Minivet and Black Bulbul were observed mostly in the canopy and the Crested Drongo was observed in the middle strata of the forest (10 to $20 \mathrm{ft}$ ). The Asian Paradise Flycatcher was observed in the same range. However, other fly catching species (Black-naped Monarch and Tickell's Blue flycatcher) were observed mostly in the 10 to $15 \mathrm{ft}$ vertical range. There was an extensive overlap of height ranges between some species. But they were observed to use different activity/feeding sites. Black-naped Monarch and Velvet-fronted Blue Nuthatch were found in the same height range, but feeding sites utilized by them was different (foliage and tree trunk respectively). Crested Drongo and Asian Paradise Flycatcher were observed to occupy the same vertical height range and feeding sites, but they were using different feeding techniques. Even being a small area of 12 ha (CEA, 1994) surrounded by Rubber plantations and home gardens, the Swamp Forest have a considerable flocking tendency with compared to Sinharaja Forest Reserve 30\%) (Kotagama et. Al., 1986) and Knuckles Conservation Forest (30.5) (Shriyani, 2000), thus worth conserve the habitat

Proceedings of the Ninth Annual Forestry and Environment Symposium 2003 of the Department of Forestry and Environmental Science, University of Sri Jayewardenepura, Sri Lanka 